\title{
Diachronic aspects of ESP
}

Diachronie et anglais de spécialité

David Banks

\section{(2) OpenEdition}

Journals

Electronic version

URL: http://journals.openedition.org/asp/4812

DOI: $10.4000 /$ asp. 4812

ISSN: 2108-6354

Publisher

Groupe d'étude et de recherche en anglais de spécialité

\section{Printed version}

Date of publication: 9 March 2016

Number of pages: $97-112$

ISSN: 1246-8185

\section{Electronic reference}

David Banks, « Diachronic aspects of ESP », ASp [Online], 69 | 2016, Online since 01 March 2017 connection on 03 November 2020. URL : http://journals.openedition.org/asp/4812 ; DOI : https:// doi.org/10.4000/asp.4812

This text was automatically generated on 3 November 2020

Tous droits réservés 


\title{
Diachronic aspects of ESP
}

\author{
Diachronie et anglais de spécialité
}

\author{
David Banks
}

\section{Introduction}

1 Diachronic linguistics is the study of language as it develops over time. It is conventionally contrasted with synchronic linguistics, which is the study of language at a single point in time without reference to the way in which it develops. These two have respectively sometimes also been called historical and descriptive linguistics (Crystal 1985, 1999; Bynon 1977). ${ }^{1}$ It is possible to have a synchronic study of a language (or some aspect of it) at a specific point in the past. However, such studies will frequently have, at least an implicit, and more usually an explicit contrast with the present state of the language, and consequently they too may be thought of as having some diachronic import. It seems incontrovertible that knowledge of the development of a language can help in the understanding of its present state. Knowing how the modal auxiliaries of present-day English grew out of full lexical verbs of Old English can help in understanding the semantic complexity of the modern modal system; knowledge of the Great Vowel Shift can be an aid to coming to terms with the apparent idiosyncrasies of contemporary English orthography. Thus, courses in the history of English have long been a standard component of curricula for advanced students of the language. I have previously argued (Banks 2011, 2012, 2015) that this could beneficially be applied to ESP, and suggested the term "diachronic ESP" for the study of diachronic aspects of ESP; others have used the term "diaESP" (Alonso-Almeida \& MarreroMorales 2011). I am not suggesting that this should necessarily be taught directly to students of ESP, but rather that teachers and trainee-teachers of ESP would benefit (and hence their teaching would benefit) from a knowledge of diachronic aspects of ESP.

2 Although very little work so far uses the term "diachronic ESP", there is a certain amount of work on the diachronic analysis of specialized text, and this may be thought of as being, at least part of, the content of diachronic ESP. Moreover, just like any text, 
understanding a specialized text from a previous period requires knowledge of the context in which it was produced. Hence this is an area where linguistics proper and cultural studies both have their importance, and thus where both linguists and specialists of cultural studies have a contribution to make.

3 Of course, specialized text is probably as old as writing. The earliest examples of written text, in the 3rd millennium B.C. were specialized in nature, and Swales (1997) points out that these display characteristics that we associate with specialized text today. Morini-Garcia (2000) also sees texts from the 3rd and 2nd millennia B.C. as " ancêtres du discours spécialisé" (2000: 565). This paper, however, will deal with ESP rather than LSP, and hence with a much shorter time-scale. The work available is fairly piecemeal, but the largest section of the jig-saw puzzle which has been tackled is that of the diachronic analysis of scientific text, so that is where I shall start. I shall look first at the contribution of sociolinguistics to the field. I shall then look at the work of Michael Halliday in this area. His profound and insightful comments are among the most interesting to have been made in this field. My own work on the development of the scientific article follows on from that of Halliday. I shall then consider the particular area of the development of medical discourse, where the work of SalagerMeyer is particularly important. In addition, I shall mention some significant books of edited collections of articles. I shall also look at the question of multimodality, where non-verbal features, notably images, form an integral part of the discourse. Finally, I shall mention some contributions in specialized translation, and in areas other than science.

\section{A sociolinguistic approach}

4 Those who work in the area of the diachronic analysis of specialized text usually take Bazerman (1988) as the seminal study in this field. Half of the chapters in this book had appeared previously as articles, and the book covers a wide range of topics, including, for example, experimental accounts in the Philosophical Transactions 1665-1800, the controversy surrounding Newton's theory of optics, and experimental reports in spectroscopy in Physical Review, 1893-1980. Bazerman's approach is that of a sociolinguist, and so he is interested in the social situation in which the text is produced, and what the text reveals about it. In the wake of Bazerman's book, a number of others appeared with a similar orientation. Gross 1996, like Bazerman's book, is based on previously published articles; ten of the twelve chapters had appeared in article form. He also deals with a range of topics, and his interest is in the rhetorical structure of scientific writing. Atkinson 1999 deals specifically with the Philosophical Transactions over the period 1675-1975, and again his interest is sociolinguistic. Valle 1999 also deals with the Philosophical Transactions from a sociolinguistic point of view, over the similar period of 1665-1965, but restricts her study to the life sciences. Gross et al. (2002) consider scientific articles in English, French and German from the 17th to the 20th century. They are interested in style, presentation and argument structure. Although they have more in the way of linguistic analysis, their quotes and examples from non-English sources are given in English translation only, showing that they are basically interested in what is said rather than how it is said. 


\section{A systemic functional approach}

5 One of the most significant contributions to this area is that of Michael Halliday within the framework, of which he was the founding father, of Systemic Functional Linguistics (Halliday 2014; Banks 2005). In Halliday 1988, he takes as his starting point the earliest known technical text written in English, Chaucer's Treatise on the Astrolabe, which dates from 1391, and which he never, in fact, completed. This is a manual of instructions for the use of an astrolabe, and was ostensibly written for his son, said to be ten years' old at the time. It is then not to be confused with something like a research article, being more like a modern teenager's "how-it-works" type of book (Banks 1995, 1997). According to Halliday, Chaucer's text is "a kind of technical, perhaps proto-scientific discourse" (1988: 165). He bases this judgement on Chaucer's use of technical nouns, complex nominal groups, events under study expressed as relational processes, and activities expressed as material or mental processes. In Systemic Functional Linguistics a process is the function typically encoded in verbs. Material processes are physical actions and events; mental processes are events of a cognitive type, and relational processes are relationships of an attributive, identifying or possessive kind. Halliday then moves on several centuries to Newton's Treatise on Opticks, which he takes as constituting the beginning of scientific English proper. This was not published until 1704 , but was probably complete by 1687 , and followed the controversial reception of his article "A new theory of light and colours" published in the Philosophical Transactions in 1672 (Fara 2002; Hakfoort 1988; Shapiro 2001). Where Chaucer's text had been instructions for use, Newton's is a discourse of experimentation: "in place of Chaucer's instructions for use he has descriptions of action - not 'you do this' but 'I did that"' (Halliday 1988: 166). Experimental activity is expressed through material processes, with mental processes being used for observation and reasoning. In the experimental sections Newton uses clause complexes (in other approaches these would usually be called sentences) with numerous subordinate clauses, but in the mathematical sections the clauses are usually simple but with long complex noun groups.

One of the most significant points that Halliday makes relates to Newton's use of the nominalization of processes. Nominalization is a way of "packaging a complex phenomenon into a single semiotic entity" (Halliday 1988: 167). Moreover, this use of nominalization is closely related to questions of thematic structure and progression. The process will frequently be expressed in its verbal form towards the end of a clause complex, where it constitutes part of the rheme, and would normally be new information. It will then appear in its nominalized form at the beginning of the following clause, thus functioning as theme and given information. This use of nominalization is therefore an important resource in the argument structure of the discourse, and this importance has increased as time has gone by. It is

an essential resource for constructing scientific discourse. We see it emerging in the language of this period, when the foundations of an effective register for codifying, transmitting and extending the 'new learning' are rapidly being laid down. (Halliday 1988: 169)

7 With this device a clause can express relationships between processes, such as "process $a$ causes process $x$ to happen". This tendency has gone on developing up to the present day, and Halliday suggests the following schematic representation of this phenomenon. 


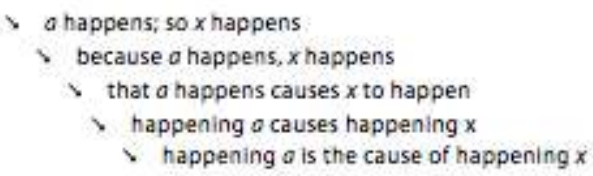

8 This does not mean that we will inevitably find the final form in contemporary texts. In fact, any of the forms could occur. What Halliday is suggesting is that over time there will be a tendency to find the later forms (Banks forthcoming a). These points are taken up again in Halliday (1993), where he gives an analysis of the final section of Darwin's On the Origin of Species by Means of Natural Selection, published in 1859. Once again he shows how the resource of nominalization enters into the thematic progression, with nominalized processes backgrounded as theme and given information. Moreover, as nouns, these processes are presented as being fixed and stable, something whose existence cannot be challenged: "the nominalization picks up on the preceding argument and presents it in this 'objectified' form as something to be taken for granted" (Halliday 1993: 98). As Halliday has said elsewhere, "you can argue with a clause but you can't argue with a nominal group” (Halliday \& Martin 1993: 39).

\section{The development of the scientific research article}

Following on from the work of Halliday, my own recent research has concentrated on the scientific research article. This is notably the case in the second half of Banks (2008) and Banks (forthcoming b). In Banks (2008) I used a corpus of articles from the Philosophical Transactions covering the period 1700 to 1980. The corpus consists of two articles for the year 1700, one from the physical sciences, and one from the biological sciences; this was repeated at 20-year intervals up to 1980, thus giving a total of 30 articles. Analysis reveals an overall picture where the physical sciences are experimental from the beginning of the period and continue to be so until the second half of the nineteenth century when mathematical modelling begins to be a major interest alongside experiment. The biological sciences were originally observational and it is only in the middle of the nineteenth century that experiment begins to be used; from then on, both experiment and observation are significant in the biological sciences. The analysis shows that in the physical sciences the use of passives increased from about $25 \%$ of finite verbs to $30 \%$ by the middle of the nineteenth century and has remained at that level since then. In the biological sciences, the rate was initially about $15 \%$, and rose to $30 \%$ in the course of the twentieth century. The use of nominalized processes seems to have been always fairly common. In the physical sciences, their frequency is about one per 30 words of text until 1920 when there is a rapid increase to about one per 14 words of text. In the biological field, the rate is less stable but settles at about one per 30 words in the mid-nineteenth century, increasing to about one per 23 words in the twentieth century. A significant development in the course of the twentieth century in the use of nominalized processes is their use as modifiers (i.e. with an adjectival function). This never occurs before 1900, but becomes fairly frequent thereafter. There are even cases where a nominal group made up of a nominalized process as modifier plus head itself functions as a complex modifier within a further nominal group, as in the following example from a 1960 article in the Philosophical Transactions, where ionization front functions as a complex modifier in the nominal group A strong R-type ionization front structure: 
A strong R-type ionization front structure with one shock is the one which is most likely to occur.

10 Analysis of the thematic structure shows that themes relating to the experimental area (that is, the object of study, the experiment or observation and the equipment used) account for $75 \%$ of all themes in the biological sector throughout the period and in the physical sector until the end of the nineteenth century. From this point on the rate falls significantly, and is replaced by themes of a mathematical nature. Thus, before 1900, examples like the following from an 1860 article are the norm:

By the addition of a little water a small quantity of syncoretin was then thrown down, in order to carry down the last traces of the less soluble crystalline compound, in case any were still present.

11 In the course of the 20th century, examples like the following, from a 1960 article, become fairly frequent accounting for over $30 \%$ over the themes:

Since $\mathrm{z}<1$ for all D-types, equation (2.11) shows that $\mathrm{v} 1<\mathrm{c} 1<\mathrm{a} 1$, so that all D-type ionization fronts move subsonically relative to the fluid ahead.

Banks (forthcoming b) concentrates on the much shorter time-scale of 1665-1700. This period was particularly important for the academic article, since in 1665 the first two academic periodicals began publication. The first was Le Journal des Sçavans on 5 January, and this was followed by the Philosophical Transactions on 5 March. ${ }^{2}$ The French journal was edited by Denis de Sallo at the instigation of Colbert. It covered the whole range of disciplines of the time, and was made up mainly of book reviews (Morgan 1928). The English journal was edited by Henry Oldenburg, one of the secretaries of the Royal Society. He was the centre of a network of correspondence (Gotti 2006), and his intention was to use his correspondence to create a newsletter as a private moneymaking venture. It was virtually restricted to the field of science and technology (Hall 2002). The year 1665 was in the middle of the reign of Louis XIV, and the situation in France was totally stable, while England was in the early days of the Restoration, and still recovering from the Civil War, the execution of Charles I, and the rule of Cromwell.

The commonest type of theme by far in the Philosophical Transactions is the object of study, which rises from $32 \%$ to $57 \%$ over the period, whereas in the Le Journal des Sçavans the commonest type of theme (37\%) relates to humans other than the author, most frequently the author of a book under review. This is consistent with a primary interest in an object of study in the English journal compared to a primary interest in humans in the French journal. An analysis of the process types of the finite verbs (Banks 2005, forthcoming c) shows that in both journals relational processes account for $30 \%$ of the finite verbs. In the Philosophical Transactions however, the most frequent process type is material, accounting for 35\%, with verbal process (processes of communication) accounting for $14 \%$. In Le Journal des Sçavans relational is the commonest process type followed by material process, $27 \%$, and verbal process $24 \%$. The incidence of relational process shows that description is important in both journals; however, physical actions and events, indicated by the use of material process is even more important in the Philosophical Transactions. The relative frequencies of verbal process show that communication is more important in the French journal than the English. Study of modality indicates that there is a significant use of deontic modality in Le Journal des Sçavans (18\% of all modal expressions), whereas this type of modality is virtually absent in the Philosophical Transactions. This results from the presence of items from such fields as theology and law in the French periodical, while these fields are absent from the pages of the English journal. Overall the results of the 
analyses show that the linguistic features depend on the editorial decisions made by Oldenburg and de Sallo about the scope and content of their respective publications. Moreover these decisions are themselves comprehensible in terms of the historical context in which they were made. This is a striking illustration of the way in which a text is intimately related to the context in which it is produced, of which it then becomes a part, and without which it cannot be fully understood. For example, the historical situation in which oldenburg finds himself leads him to produce a journal restricted to the scientific and technical fields, because that is what his potential audience were interested in, but this leads to increased use of material processes (usually expressing physical events, or recounting experiments), whereas de Sallo's brief leads him to opt for book reviews covering the whole spectrum of disciplines of the time, and this leads to increased use of verbal processes (usually expressing what is said in the books under review).

Shorter studies of the scientific article would include such contributions as Magnet (2000) which analyses the discussion sections of articles in the area of nutrition studies over a period from 1929 to the 1990s. She notes that the length of discussion sections falls from an average of 850 words before 1960 to 625 words during the 1960s; this trend is however reversed after 1990 when the length rises sharply to an average of 1300 words. There is an increasing use of quotes and the discussion section in the later part of the period "participe fortement à la stratégie de validation de l'expérience" (2000: 125).

\section{Medical discourse}

Within the general scientific field, medicine holds a particular position. Salager-Meyer has studied a number of features of medical discourse from a diachronic point of view. These can all be considered to be more or less related to interpersonal aspects of the language. In Salager-Meyer et al. (1996), and Salager-Meyer and Defives (1998), the authors looked at hedging in medical articles from the nineteenth and twentieth centuries. They distinguish between shields (i.e. basically, expressions of epistemic modality), use of the passive, approximators, expressions of doubt, and emotionally charged intensifiers. They find that shields and expressions of doubt were rare in the nineteenth century but became common in the twentieth century. The opposite is true of approximators and emotionally charged intensifiers, which are common in the nineteenth but not in the twentieth century. The use of passives increases from the end of the nineteenth century onwards, with the period of most rapid change being 1930 to 1960.

16 In Salager-Meyer (1999a, 1999b) she considers the question of citations in medical discourse over the period 1810 to 1995. In (1999a) she distinguishes between those references which are critical and those which are not. She finds that until 1930 critical and non-critical references occur with more or less the same frequency, but from 1930 onwards there is a rapid increase in the number of non-critical references from about four per paper to twenty per paper by the end of the period. In comparison there is only a slight rise in the number of critical references. She notes that "earlier papers adopted a much more critical tone than modern ones" (1999a: 19), but that before the twentieth century criticism was usually preceded by courtesy markers. In nineteenth century papers, criticism is scattered throughout the paper, whereas in the twentieth century, where it occurs, it is usually restricted to the introductory section. She 
comments on the importance of the sociological environment in determining these interpersonal aspects of the text:

[S]ocietal development is a determining factor in the changing of textual patterns, and that persistence and change in the social system are both reflected in the text and brought about by means of text, i.e. that determining factors of linguistic change are intimately linked to and brought about by the social, historical and cultural context in which discourse is produced. (Salager-Meyer 1999a, 26-27)

The question of criticism is also raised in Salager-Meyer (1998), and Salager-Meyer and Zambrano (2001). They distinguish direct and indirect academic conflict in English and French medical discourse. These occur at the same rate in both languages during the period 1810 to 1930. In this period, criticism is provocative and highly polemical, though in the English papers the criticism is frequently preceded by courtesy markers, which is not the case in the French papers. From 1930 onwards criticism in the English papers becomes less personalized and more object-centred, but the French papers remain fairly aggressive until the late twentieth century.

\section{Edited collections}

18 In recent years there have been a number of collections of papers dealing with diachronic aspects of specialized text. To continue the medical theme, Taavitsainen and Pahta (2011) contains twelve contributions all using Early Modern English Medical Texts, a computerized corpus of just over two million words, which is itself the second of three components which make up the Corpus of Early English Medical Writing. This second component covers the period 1500 to 1700 and includes general and specific treatises, medical recipe collections, health guides, and articles from the Philosophical Transactions. The contributions cover such questions as use of cognitive verbs, definitions, code-switching, controversy and advertising, the development of specialized discourse, and the expression of stance.

19 Moskowich and Crespo (2012) is also based on a computerized corpus, the Corpus of English Texts on Astronomy; again this is part of a larger corpus: the Coruña Corpus of English Scientific Writing. As the title indicates it is devoted to texts in the field of astronomy and covers the period 1700 to 1900 . The eleven contributions which make up the book cover such questions as use of adjectives, new nouns and specific vocabulary, complex predicates, the pattern $N+P R E P+V$-ing, hedging and thematic structure.

Diachronic aspects of specialized translation are considered in Duris (2008). This is not specifically about translation to or from English, so it is LSP rather than ESP. Only one of the nine contributions concerns English, and deals with early translations of Newton's Opticks into French (Baillon 2008).

21 My own edited volume (Banks 2010a) is, again, not totally devoted to English but four of the twelve contributions do deal specifically with English texts, covering topics such as referring to others in academic articles over the period 1700 to 1980 (Banks 2010b), continental drift in the nineteenth century (Château 2010), translations into French of Darwin's The Descent of Man (Engel-Gautier 2010), and the use of illustrations in The Lancet, over the period 1823 to 1905 (Rowley-Jolivet 2010). 


\section{Multimodality}

22 The final item mentioned above falls into the domain of multimodality, a field of study that has grown rapidly over the last couple of decades, particularly in the wake of Kress and van Leeuwen (1996). Multimodality takes into account all aspects of communication, not just those that are verbal, and the area that has attracted most attention is the contribution made by visual elements in a text. In this article (RowleyJolivet 2010), the author shows that over the period 1823 to 1905, images in the Lancet, which were basically figurative, evolved only slowly and in erratic fashion. It was only towards the end of this period that visual conventions in the medical article began to be established. Magnet (2001) looks at the development of images in the area of nutrition studies over a seventy-year period up to the 1990s. She notes that the space allotted to visuals does not increase over this period, but that their nature has changed:

[T] he widespread use of computers has only made the production of data easier, quicker and has therefore led to the amplified treatment and display of quantitative measurements, while photography, a more expensive and less rewarding tool has almost totally disappeared. (2001: 72-73)

Two of the contributions in my edited volume, Banks 2013a, are of interest in the field of ESP. Somerset 2013 analyses the illustrations in Arabella Buckley's nineteenth century popularizations of the theory of evolution. My own contribution (Banks 2013b) considers the images in early issues of the Philosophical Transactions for the period 1665 to 1670, a subject which I had previously considered in Banks (2009). One of the interesting features revealed by this study is an apparent circular organization of the images on the page.

While the literature on multimodality as such is vast, studies which treat the question from a diachronic standpoint are relatively rare. Similarly, there are many histories of the development of images in specialized documents, and while these might provide interesting background for studies in diachronic multimodality, they lack the linguistic component which would bring them into the field of diachronic ESP.

\section{Translation and lexicology}

Translation has always been with us, and indeed the first translation of an academic article from French to English dates from 1665 and appeared in the first issue of the Philosophical Transactions, the original French having appeared in the first issue of Le Journal des Sçavans (Banks forthcoming d). The development of translation and translation techniques could be a fruitful area of enquiry for diachronic ESP. Duris (2008) and Engel-Gautier (2010) have been mentioned above. To these could be added Dury (2005) and Dury and Lervad (2008). These are diachronic studies of terminology in the context of specialized translation. In (Dury 2005), based on a corpus from the area of ecology, the author notes that terms do not conserve the same meaning either over time or from language to language. Thus a concept may evolve, but the term used to designate it will not necessarily be modified. Dury and Lervad (2008) is based on a corpus of texts in mineralogy (more specifically relating to petroleum), covering the period 1800 to 1960 . They show how initial synonymic variation can lead to specialization. 


\section{Other than science}

26 All of the above may give the impression that diachronic ESP is a question of the diachronic analysis of scientific discourse. This is only because this is the area which has so far received the lion's share of attention, but all other specialized areas are potential fields of study. Although excursions into these areas are rarer, the following might be cited as examples.

27 Wagner (2003) considers the evolution of legal language in English. The legal language of England had passed from Latin to French by the thirteenth century, and gradually moved to English from the mid-fourteenth century when pleas in English were permitted. The result is that "current legal language is a mixture of Latin, Old English and Norman French" (2003:103).

28 Taavitsainen (1994) compared religious texts from late Middle English with scientific texts from that date up to the late seventeenth century. She brings out the relevance of sub-genre differences. Underestimating sub-genre differences is something which Biber and Gray (2013) have also recently warned against.

29 It is also possible to study the development of language in more restricted and exotic fields. Wozniak (2015), for example, looks at the evolution of the discourse of mountaineering from 1870 onwards.

\section{Final remarks}

30 An overview of this type can never hope to be exhaustive, and I am sure that many readers will be able to think of work which might have been included, but which has not been mentioned here, partly, no doubt, a reflection of my own personal interests. With due apologies to any authors concerned, I hope nevertheless that this gives a fair picture of the current situation of diachronic ESP. As can be seen from the above, the area that has received most attention is the analysis of scientific text, but even here, what is available is sparse and scattered, and there is vast scope for further research. In areas other than science, there are no more than a few fairly isolated studies, so the field is wide open.

31 I am one of those who believe that there is an intimate relationship between a text and its context. A text is produced in, and, in some senses, by its context, of which it then becomes a part. Thus the context produces the text, but the text then modifies the context, so that there is a continual cause and effect operating between the two. In studying diachronic texts this is felt all the more strongly as the contexts in which they were produced are no longer immediately available to us. This can be seen in the differences between early issues of the Philosophical Transactions and Le Journal des Sçavans mentioned above. In my work on late seventeenth century scientific writing, I have found it necessary to read up on the history, and particularly the history of science of the period. Thus this is an area which can combine both linguistics and cultural studies. Just as Petit's seminal work on FASP (Petit 1999) opened up a research space where those working in ESP, but with an interest in literature could find a place, I would like to think that diachronic ESP could provide a research niche (Swales 1990, 2004) for those working in ESP but who have an interest in cultural studies. 

present dominance of English as the language of academic science, and increasingly in many other areas including the humanities, seems so well entrenched as to be virtually a permanent fixture. So it is useful to remember that this is a relatively recent development, probably much more recent than most people realize. Ammon (2012), who studied the period 1880 to 2005 , shows that while articles in scientific periodicals, which are written in English, account for over $90 \%$ of the total since the mid-1990s, they accounted for only 50\% in 1960, showing that there has been a rapid increase in the use of English in the second half of the twentieth century. Going a little further back in time, in 1910, English accounted for only 30\% of scientific articles published, and at that time German accounted for a higher percentage of the publications than English; English only overtook German in about 1930. So for a period of about twenty years in the early twentieth century, German, not English, could be seen as the dominant language of science (Gordin 2015). In the social sciences, the percentage of articles published in English increased from 48\% in 1951 to 76\% in 2005.

Work in this area need not be restricted to a particular theoretical approach. As can probably be seen from the above, work that has been done so far has usually been within a more or less functional approach, and this type of approach seems well suited to the task; but this should not be seen as being to the exclusion of other possible approaches, for example cognitive. There are also data banks of texts such as Gallica, the website of the French Bibliothèque Nationale. This is a vast mine of texts, but usually in image form, so not immediately suitable for lexicometrical work. Where text analysis is involved this can be either manual or computerized. Computerized approaches require suitable corpora, and several are already available, such as those mentioned above. This type of approach can treat large quantities of data, but is restricted to features which the machine can recognize. A manual approach is more flexible, but can only deal with a limited quantity of data. I feel that computerized and manual analyses are suitable for rather different types of task and that both have a part to play.

Hence this is a research field where some inroads have been made, but where there are still vast tracts of virgin territory. I would like to think that established researchers in linguistics with an interest in cultural studies, or vice-versa will find new avenues to be explored in this field, and that novice researchers will find a research space in which to exercise their talents.

I would like to thank three anonymous ASp reviewers, whose comments have enabled me to improve this article. It goes without saying that they are in no way responsible for any shortcomings which remain.

\section{BIBLIOGRAPHY}

ALONSO-ALMEIDA, Francisco \& Sandra ARRERO-MORALES. 2011. "Introduction: Diachronic English for Specific Purposes”. Revista de Lenguas para Fines Especificos 17, 13-20. 
AMMON, Umrich. 2012. "Linguistic inequality and its effects on participation in scientific discourse and on global knowledge accumulation - With a closer look at the problems of the second-rank language communities". Applied Linguistics Review 3/2, 333-355.

ATKINSON, Dwight. 1999. Scientific Discourse in Sociohistorical Context. The Philosophical Transactions of the Royal Society of London, 1675-1975. Mahwah, NJ: Lawrence Erlbaum Associates.

BAILLON, Jean-François. 2008. "Retraduire la science. Le cas de l'Optique de Newton, de Pierre Coste (1720) à Jean-Paul Marat (1787)". In DURIS, P. (Ed.), Traduire la science, hier et aujourd'hui. Pessac: Maison des Sciences de l'Homme de l'Aquitaine, 69-88.

BANKS, David. 1995. "Your very first ESP text (wherein Chaucer explaineth the astrolabe)". ASp 15-18, 451-460.

BANKS, David. 1997. "Little Lewis and Chaucer's astrolabe, Instructions for use in the fourteenth century”. In BANKS, D. \& A. TSÉDRI (Eds.), Sons et Sens, Mélanges offerts à Jean François Raoult. Brest: ERLA, Université de Bretagne Occidentale, 56-72.

BANKS, David. 2005. Introduction à la Linguistique systémique fonctionnelle de l'anglais. Paris: L'Harmattan.

BANKS, David. 2008. The Development of Scientific Writing, Linguistic features and historical context. London: Equinox.

BANKS, David. 2009. "Notes on illustrations in some early issues of the Philosophical Transactions”, In SLEMBROUCK, S., M. TAVERNIERS \& M. VAN HERREWEGHE (Eds.), From will to well, Studies in linguistics offered to Anne-Marie Simon-Vandenbergen. Gent: Academia Press, 21-41. BANKS, David (Ed.). 2010a. Aspects diachroniques du texte de spécialité. Paris: L'Harmattan. BANKS, David. 2010b. "La référence à autrui dans l'article de recherche scientifique, 1700-1980". In BANKS, D. (Ed.) 2010a, 7-20.

BANKS, David. 2011. “The place of diachronic studies in LSP”. Moderne Sprachen 55/2, 177-189.

BANKS, David. 2012. "Diachronic ESP: at the interface of linguistics and cultural studies". ASp 61, $55-70$.

BANKS, David (Ed.). 2013a. L'image dans le texte scientifique. Paris: L'Harmattan.

BANKS, David. 2013b. "Les premières images de la revue scientifique : Les Philosophical Transactions, 1665-1670". In BANKS, D. (Ed.) 2013a, 41-64.

BANKS, David. 2015. "Domains of study and genres in late seventeenth century science: evidence from the Philosophical Transactions of the Royal Society (1675)". Text \& Talk 35/3, 317-336, <Doi 10.1515/text-2015-0002>.

BANKS, David. forthcoming a. "SFL and diachronic studies" in BOWCHER, W.L., L. FONTAINE, J.Y. LAING \& G. THOMPSON (Eds.), The Cambridge Handbook of Systemic Functional Linguistics. Cambridge: Cambridge University Press.

BANKS, David. forthcoming b. The Birth of the Academic Article. Le Journal des Sçavans and the Philosophical Transactions, 1665-1700. Sheffield: Equinox.

BANKS, David. forthcoming c. "On the (non)necessity of the hybrid category Behavioural process". In MILLER, D.R. \& P. BAYLEY (Eds.), Hybridity in Systemic Functional Linguistics, Grammar, text and discourse. Sheffield: Equinox. 
BANKS, David. forthcoming d. "L'écriture de l'article scientifique et ses premières traductions". In THORNBORROW, J. \& J.-Y. LE DISEZ (Eds.), Traduire/écrire la science aujourd'hui. Rennes: Presses Universitaires de Rennes.

BAZERMAN, Charles. 1988. Shaping Written Knowledge. The genre and activity of the experimental article in science. Madison, WI: University of Wisconsin Press.

BIBER, Douglas \& Bethany GRAY. 2013. "Being specific about historical change: the influence of subregister". Journal of English Linguistics 41/2, 104-134.

BYNON, Theodora. 1977. Historical Linguistics. Cambridge: Cambridge University Press.

CHÂTEAU, Carmela. 2010. "Suivre la dérive de "continents" dans un corpus diachronique d'anglais géologique". In BANKS, D. (Ed.), 2010a, 21-34.

CRYSTAL, David. 1985. A First Dictionary of Linguistics and Phonetics. London: André Deutsch.

CRYSTAL, David. 1999. The Penguin Dictionary of Language, 2nd. edn. London: Penguin.

DURIS, Pascal (ed.). 2008. Traduire la science. Hier et aujourd'hui. Pessac: Maison des Sciences de l'Homme d'Aquitaine.

DURY, Pascaline. 2005. "Terminology and specialized translation: the relevance of the diachronic approach". LSP \& Professional Communication 5/1, 31-41.

DURY, Pascaline \& Susanne LERVAD. 2008. "La variation synonymique dans la terminologie de l'énergie : approches synchronique et diachronique, deux études de cas". LSP \& Professional Communication 8/2, 66-79.

ENGEL-GAUTIER, Carolyn. 2010. "Retranslating scientific works: The case of Darwin's the Descent of Man”. In BANKS, D. (Ed.), 2010a, 35-52.

FARA, Patricia. 2002. Newton. The Making of Genius. London: Picador.

GORDIN, Michael D. 2015. Scientific Babel: The language of science from the fall of Latin to the rise of English. London: Profile Books.

GOTTI, Maurizio. 2006. "Disseminating early modern science: specialized news discourse in the Philosophical Transactions". In BRownLEES, N. (Ed.). News Discourse in Early Modern Britain. Peter Lang: Bern, 41-70.

GROSS, Alan G. 1996. The Rhetoric of Science, 2nd edn. Cambridge, MA: Harvard University Press. GROSS, Alan G., Joseph E. HARMAN \& Michael REIDY. 2002. Communicating Science. The scientific article from the 17th century to the present. Oxford: Oxford University Press.

HAKFOORT, Casper. 1988. "Newton's optics: the changing spectrum of science”. In FAUVEL, J., R. FLOOD, M. SHORTLAND \& R. WILSON (Eds.), Let Newton Be! Oxford: Oxford University Press, 82-99.

HALL, Marie Boas. 2002. Henry Oldenburg, Shaping the Royal Society. Oxford: Oxford University Press. HALLIDAY, M.A.K. 1988. “On the language of physical science”. In GHADESSY, M. (Ed.), Registers of Written English: Situational factors and linguistic features. Pinter: London, 162-178. [reprinted in HALLIDAY, M.A.K. \& J.R. MARTIN 1993. Writing Science. Literacy and discursive power. The Falmer Press: London, 54-68; and HALLIDAY, M.A.K. (Ed. Jonathan Webster). 2004. The Language of Science. Continuum: London, 140-158]

HALLIDAY, M.A.K. 1993. "The construction of knowledge and value in the grammar of scientific discourse, with reference to Charles Darwin's The Origin of Species". In HALLIDAY, M.A.K. \& J.R. 
MARTIN, Writing Science. Literacy and discursive power, The Falmer Press: London, 86-105. [reprinted in COULTHARD, M. (Ed.). 1994. Advances in Written Text Analysis, Routledge: London, 136-156, and Ë, M.A.K. (Ed. Jonathan J Webster). 2002. Linguistic Studies of Text and Discourse. Continuum: London, 168-195.]

HALLIDAY, M.A.K. (revised by Christian M.I.M. MATTHIESSEN). 2014. Halliday's Introduction to Functional Grammar, 4th edn. London: Routledge.

HALLIDAY, M.A.K. \& J.R. MARTIN. 1993. Writing Science. Literacy and discursive power. London: Falmer Press.

KRESS, Gunther \& Theo VAN LEEUWEN. 1996. Reading Images, the grammar of visual design. London: Routledge.

MAGNET, Anne. 2000. "Stratégies de validation du discours scientifique : analyse diachronique du rôle de la section Discussion dans l'article de recherche". ASp 27-30, 123-132.

MAGNET, Anne. 2001. "Diachronic analysis of the visuals in the research paper: a corpus-based study of the strategies and semiotics of visual representation in nutrition biochemistry". LSP \& Professional Communication 1/1, 55-77.

MORGAN, Betty Trebelle. 1928. Histoire du Journal des Sçavans depuis 1665 jusqu'en 1701. Paris: Presses Universitaires de France.

MORINI-GARCIA, Pascale. 2000. "De l'image au texte : quelques repères historiques". ASp 27-30, 563569.

MOSKOWICH, Isabel \& Begoña CRESPO (Eds.). (2012). Astronomy 'playne and simple'. The writing of science between 1700 and 1900. Amsterdam: John Benjamins.

PETIT, Michel. 1999. “ La fiction à substrat professionel : une autre voie d'accès à l'anglais de spécialité". ASp 23-26, 57-84.

ROWLEY-JOLIVET, Elizabeth. 2010. "The evolution of medical imagery in the 19th century: The Lancet ", 1823-1905. In BANKS, D. (Ed.), 2010a, 53-74.

SALAGER-MEYER, Françoise. 1998. "Le discours aigre-doux de la controverse scientifique : évolution de la rhétorique des confrontations académiques". ASp 19-22, 29-50.

SALAGER-MEYER, Françoise. 1999a. “From 'Mr. Guthrie is profoundly mistaken...' to 'Our data do not seem to confirm the results of a previous study on...': A diachronic study of polemicity in academic writing (1810-1995)". Iberica. Revista de la Asociasión Europea de Lenguas para Fines Especificos 1, 5-28.

SALAGER-MEYER, Françoise. 1999b. "Referential behavior in scientific writing: a diachronic study (1810-1995)”. English for Specific Purposes 18/3, 279-305.

SALAGER-MEYER, Françoise, Gérard DEFIVES \& Miguel HAMELYNCK. 1996. “A diachronic study of hedges in medical English written discourse”. In BuDIN, G. (Ed.), Multilingualism in Specialist Communication; Proceedings of the 10th European LSP Symposium, Vol.1. Vienna: IITF/Infoterm, 267286.

SALAGER-MAYER, Françoise \& Gérard DEFIVES. 1998. "From the gentleman's courtesy to the expert's caution: a diachronic analysis of hedges in academic writing (1810-1995)". In FORTANET, I., S. Posteguillo, J.C. PALmer \& J.F. coll (Eds.), Genre Studies in English for Academic Purposes. Castelló de la Plana: Publications de la Universitat Jaume I, 133-171. 
SALAGER-MEYER, Françoise \& Nahirana ZAMBRANO. 2001. "The bittersweet rhetoric of controversiality in nineteenth- and twentieth-century French and English medical literature". Journal of Historical Pragmatics 2/1, 141-173.

SHAPIRO, Alan E. 2001. "Newton's experiments on diffraction and the delayed publication of the Opticks”. In BuchWALD, J.Z. \& I.B. COHEN (Eds.), Isaac Newton's Natural Philosophy. Cambridge, MA: MIT Press, 47-76.

SOMERSET, Richard. 2013. “Raconter l'évolution en images : la vulgarisation d'Arabella Buckley". In BANKS, D. (Ed.) 2013a, 65-82.

SWALES, John M. 1990. Genre Analysis: English in academic and research settings. Cambridge: Cambridge University Press.

SWALES, John M. 1997. “The world's earliest known technical texts: a brief note”. English for Specific Purposes 16/2,151-152.

SWALES, John M. 2004. Research Genres: Exploration and applications. Cambridge: Cambridge University Press.

TAAVITSAINEN, Irma. 1994. "Subjectivity as a text-type marker in historical stylistics". Language and Literature 3/3, 197-212.

TAAVITSAINEN, Irma \& Päivi PAHTA (Eds.). 2011. Medical Writing in Early Modern English. Cambridge: Cambridge University Press.

VALLE, Ellen 1999. A Collective Intelligence. The life sciences in the Royal Society as a scientific discourse community, 1665-1965. Turku: Anglicana Turkuensia.

WAGNER, Anne. 2003. "Origins and use of English legal terms through history”. LSP \& Professional Communication 3/2, 92-106.

WOZNIAK, Séverine. 2015. “Étude des domaines spécialisés et de leurs discours en diachronie : le cas des genres spécialisés de la littérature d'alpinisme aux États-Unis”. ASp 67, 81-99.

\section{NOTES}

1. The nature of this paper is such that some references are given as examples, without implying that they are the sole references possible.

2. Both of these periodicals still exist, and have been published with only minor interruptions since 1665 , although their contents has to some extent altered in the course of three and a half centuries. (Just as I was finishing this paper, Notes and Records, the history of science journal of the Royal Society produced a special issue devoted to "350 years of scientific periodicals").

\section{ABSTRACTS}

Diachronic ESP is a relatively new field of research, and much of the work which might be included under this title does not use this term. This paper attempts to give an overview of the 
work available. Early contributions tended to be in the field of sociolinguistics. The work of Michael Halliday is particularly important, notably his studies of the relationship between nominalization and thematic progression. The work of Banks on the scientific research article follows on from that of Halliday, and looks specifically at the Philosophical Transactions, and compares it with the French Journal des Sçavans. Salager-Meyer has made a significant contribution in the area of interpersonal aspects of medical discourse. There has also been a small number of edited collections on the question of the development of scientific discourse. Some of the studies are multimodal in nature, dealing particularly with the uses of images in scientific text. The majority of studies in this area have been on scientific text, but there have been sporadic sorties into other genres. Diachronic ESP should provide a fruitful field for future research.

L'anglais de spécialité (ASP) diachronique constitue un champ de recherche relativement nouveau, bien que de nombreux travaux qui pourraient figurer sous cet intitulé n'utilisent pas cette expression. Cet article tente de dresser un état des lieux de la recherche dans ce domaine. Les premières contributions étaient souvent de nature sociolinguistique. Les travaux de $\mathrm{M}$. Halliday sont particulièrement intéressants, notamment ses études sur la relation entre la nominalisation et la progression thématique. Ceux de Banks sur l'article de recherche scientifique se situent dans le prolongement de ceux de M. Halliday; ils traitent principalement des Philosophical Transactions et les comparent avec le périodique français, le Journal des Sçavans. F. Salager-Meyer fournit une contribution majeure à propos des aspects interpersonnels du discours scientifique. Des ouvrages collectifs sur la question de l'évolution $\mathrm{du}$ discours scientifique ont aussi été publiés. Certaines études sont plurimodales de nature et traitent en particulier de l'usage des images dans le texte scientifique. La majorité des études dans ce domaine concerne le discours scientifique, mais quelques tentatives ponctuelles ont porté sur d'autres types de discours. L'ASP diachronique devrait être un champ fructueux pour la recherche future.

\section{INDEX}

Keywords: diachronic ESP, Journal des Sçavans, multimodality, Philosophical Transactions, scientific discourse, systemic functional linguistics

Mots-clés: anglais de spécialité diachronique, discours scientifique, Journal des Sçavans, linguistique systémique fonctionnelle, Philosophical Transactions, plurimodalité

\section{AUTHOR}

\section{DAVID BANKS}

David Banks is Emeritus Professor at the Université de Bretagne Occidentale in France. He is former Head of the English Department, Director of ERLA (Équipe de recherche en linguistique appliquée) and Chairman of AFLSF (Association française de la linguistique systémique fonctionnelle). He is author or editor of thirty books and has published 100 academic articles. His publication The Development of Scientific English, Linguistic features and historical context (Equinox) won the ESSE Language and Linguistics book award 2010. His research interests include the diachronic study of scientific text and the application of systemic functional linguistics to English and French. His non-academic activities include choral singing and ocean rowing. david.banks@univ-brest.fr 